\title{
The Influence of $\mathrm{ZnCl}_{2}$ Activation on Macronutrient NPK Adsorption Simultaneously Using Coconut Shell Biochar for Soil Fertility Improvement
}

\section{Candra Purnawan ${ }^{1 *}$, Christina Candra Dewi ${ }^{1}$,Syafrudin ${ }^{2}$, Bimastyaji Surya Ramadan ${ }^{2}$, Mochamad Arief $^{2}$ Budihardjo ${ }^{2}$, Agus Jatnika Effendi ${ }^{3}$, Syarif Hidayat ${ }^{3}$}

\author{
'Department of Chemistry, Faculty of Mathematics and Natural Sciences, Sebelas Maret University, \\ Surakarta 57126, Central Java, Indonesia \\ ${ }^{2}$ Department of Environmental Engineering, Faculty of Engineering, Diponegoro University, \\ Semarang, Central Java, Indonesia \\ ${ }^{3}$ Department of Environmental Engineering, Faculty of Engineering, Bandung Institute of Technology, \\ Bandung, West Java, Indonesia
}

*Corresponding author email: candra_pr@staff.uns.ac.id

Received October 19, 2020; Accepted February 24, 2021; Available online March 25, 2021

\begin{abstract}
The influence of $\mathrm{ZnCl}_{2}$ activation on macronutrient Nitrogen, Phosphor, Potassium (NPK) adsorption simultaneously using Coconut Shell Biochar for soil fertility improvement has been conducted. Biochar formation is carried out at temperature up to $500^{\circ} \mathrm{C}$ using variation in the concentration of $\mathrm{ZnCl}_{2} 0,5 ; 1,0 ; 1,5 ; 2,0$; dan $2,5 \mathrm{M}$. The biochar formed was characterized using Fourier Transform InfraRed (FTIR) spectroscopy and Surface Area Analyzer (SAA). Whereas NPK analysis has used the Indonesian standard method (SNI 7763: 2018). Based on this research, it was concluded that the greater the concentration of $\mathrm{ZnCl}_{2}$ activator, indicated that the higher intensity of the spectra of $-\mathrm{OH}$ and $-\mathrm{NH}_{2}$ at wave number $3400 \mathrm{~cm}^{-1}$ and $1600 \mathrm{~cm}^{-1}$. It showed that biochar activation was higher and a more active functional group was opened. Increasing the concentration of $\mathrm{ZnCl}_{2}$ activator has increased Biochar adsorption of NPK macronutrients. The optimum condition for activation of coconut shell Biochar was activation with $\mathrm{ZnCl}_{2} 2.5 \mathrm{M}$. The addition of activated Biochar was increased soil adsorption on NPK macronutrients. Biochar addition had increased Nitrogen (N) adsorption up to $23.53 \%$, Phosphor (P) up to $200 \%$, and Potassium (K) up to $41.24 \%$.
\end{abstract}

Keywords : Coconut Shell Biochar, macronutrients NPK, $\mathrm{ZnCl}_{2}$

\section{INTRODUCTION}

Indonesia has areas that are still classified as dry and barren regions such as Wonogiri, Sragen, Purwodadi, Blora, eastern Pati. The dry and barren land has a low fertility rate which causes very low agricultural productivity and cannot even be planted with food crops. The low soil fertility is caused by low nutrient content in the soil, one of which is the macronutrient elements of Nitrogen, Phosphor and Potassium (NPK). Wijayanti, Susatyo, Kurniawan, \& Sukarjo (2018) had explained that land contains chemical compounds as a result of a series of chemical reactions in nature that is strongly influenced by various factors around it, these factors will greatly affect the quality of the content of compounds in the soil. Hawkesford et al. (2012) reported the proportion of macronutrients is 3.5\% (> $10 \mathrm{mmol} / \mathrm{kg}$ BK or $>1,000 \mathrm{ppm}$ ) in the soil. Low organic matter such as NPK macronutrients is one of the main problems that causes low productivity of paddy fields. Nitrogen plays an important role in the formation of plant cells, tissues and plant organs. Then, Phosphor is a structural element in nucleic acids and plays a role key in energy transfer as a component of adenosine phosphate. This is also important for the transfer of carbohydrates in leaf cells. Whereas Potassium is an important osmoregulation for cell extension and stomata movement.

Tanasale, Killay, \& Laratmase (2012) explained the unfertilized soil is due to low soil ability to macronutrient adsorption by soil and plants. Therefore, efforts are needed to increase the NPK macronutrient content in the soil. One of the efforts that can be done to increase the absorption ability of the soil against NPK macronutrients is by adding adsorbents that can increase the absorption of these macronutrients. Effective adsorbents are adsorbents that have high selectivity and capacity and can be used repeatedly. Pambayun, Yulianto, Rachimoellah, \& Putri (2013) reported that one of the effective adsorbents is activated carbon or biocharcoal. Raw materials that can be made into Biochar are all materials that contain carbon, both derived from plants (biomass), animals or minerals. In recent years, there have been many studies on the 
preparation of activated carbon or Biochar and the application of activated carbon from various precursors such as tea residues, orange peels, Coconut shells, Poplar wood, Apricots, Date holes, and Rice husks, Coconut shells (Belaroui, Seghier, \& Hadiel, 2014; Cazetta et al., 2011; Demiral, \& Uzum, 2010; El-Dars, Ibrahim, \& Gabr, 2014; Gurten, Ozmak, Yagmur, \& Aktas, 2012; Lapanporo, \& Putra, 2013; Bedia, Mirosol, \& Cardero, 2010). Praing, Situmeang, \& Mahardika (2018) state that Coconut shell is the best active carbon material because it has a lot of micropores, low ash content, high reactivity, and high resistance in the soil. Coconut shell activated carbon can increase the efficiency of using Nitrogen fertilizer $(N)$ and increase the efficiency of water use. Mistar, Ahmad, Muslim, Alfatah, \& Supardan (2017) explained that activated carbon consists of $87-97 \%$ Carbon and other components are Oxygen, Hydrogen, Sulfur, Nitrogen, and other compounds. And then Idrus et al., (2013) reported that activated carbon has a surface area of about 300 to 2000 $\mathrm{m}^{2} / \mathrm{g}$, whereas Esterlita and Herlina (2015) reported that absorption of activated carbon is $82.04 \%$ of the weight. Masitoh and Sianita (2013) reported that activated carbon is able to adsorb anions, cations, and molecules in the form of organic and inorganic compounds.

Ramdja, Halim, \& Handi (2008) explained that carbon can be activated using physical and chemical activation to increase the adsorption ability. The chemical activation process provides many advantages, such as low activation temperature, activation time, activation step and better porous structure. In this study $\mathrm{ZnCl}_{2}$ was used because it has several advantages. During the activation process, $\mathrm{ZnCl}_{2}$ also has functions as a dehydration agent, inhibits the formation of tar, and also directs the reaction of char formation at temperatures below $500{ }^{\circ} \mathrm{C}$. Concentration of $\mathrm{ZnCl}_{2}$ will affect the character and adsorption ability of Biochar. From the description above, this study aims to determine the effect of $\mathrm{ZnCl}_{2}$ activation with optimum concentration and composition on Biochar made from Coconut shell as an adsorbent. So that the Biochar can increase the ability to adsorb macronutrients NPK in the soil.

\section{EXPERIMENTAL SECTION}

The apparatus was used in this research are Oven, glassware, 80 mesh sifter, FTIR and SAA. Meanwhile, the materials used in this study are dried Coconut shell, $\mathrm{ZnCl}_{2}$ solution $(0.5 ; 1.0 ; 1.5 ; 2.0$; and $2.5 \mathrm{M})$ and $1000 \mathrm{ppm}$ NPK fertilizer solution. Dry Coconut shell is heated at temperatures up to $500^{\circ} \mathrm{C}$ under conditions of little oxygen. The Coconut shell charcoal samples produced are then mashed and sieved using 80 mesh sieves. Charcoal is activated using a $\mathrm{ZnCl}_{2}$ activator solution with a concentration variation of $0.5 ; 1,0 ; 1,5 ; 2.0$; and $2.5 \mathrm{M}$. Activation is done by mixing Coconut shell charcoal in an activator solution with a ratio between the mass of charcoal and activator volume of $1: 4$. The mixture is stirred using a magnetic stirrer for one hour. The mixture is then allowed to stand for 24 hours. The resultant activation is washed using distilled water until it is chloride free. Neutral charcoal has been roasted for 180 minutes with a temperature of 110 ${ }^{\circ} \mathrm{C}$. Then the results obtained will be characterized by FTIR and SAA.

A total of 1 gram activated Biochar of Coconut shell that has been used as adsorben NPK in $100 \mathrm{ml}$ of $1000 \mathrm{ppm}$ NPK solution for 60 minutes. The optimum ability of activated Biochar adsorption is then used to mix the soil. The Coconut shell activated carbon is used as a soil mixture, with a ratio of $10 \%$ activated Biochar and $90 \%$ soil used for NPK adsorption to be compared with soil without activated carbon.

\section{RESULTS AND DISCUSSION}

Tanasale, Killay, \& aratmase (2012) explained the unfertilized soil is due to low soil ability to macronutrient adsorption by soil and plants. Therefore, efforts are needed to increase the NPK macronutrient content in the soil. One of the efforts that can be done to increase the absorption ability of the soil against NPK macronutrients is by adding adsorbents that can increase the absorption of these macronutrients. Effective adsorbents are adsorbents that have high selectivity and capacity and can be used repeatedly. One of the effective adsorbents is activated carbon or biochar. In order to increase the ability of adsorption, Coconut shell charcoal is activated using $\mathrm{ZnCl}_{2}$ with a concentration of 0.5 ; 1,$0 ; 1,5 ; 2.0$; and $2.5 \mathrm{M}$. Then Biochar formed was then characterized using FTIR and SAA. Biochar characterization results are as shown in Figure 1.

Figure 1 shows FTIR spectra of Biochar with $\mathrm{ZnCl}_{2}$ activator variations. It show a change in absorption peak at wave numbers around $3400 \mathrm{~cm}^{-1}$ and 1600 $\mathrm{cm}^{-1}$ as the concentration of activator $\mathrm{ZnCl}_{2}$ changed. The spectra at wave numbers around $3400 \mathrm{~cm}^{-1}$ show the overlapping vibrations of the primary $-\mathrm{OH}$ and $-\mathrm{NH}_{2}$ functional groups. While, the spectra at wave numbers around $3400 \mathrm{~cm}^{-1}$ show the bending vibrations of the primary $-\mathrm{OH}$ and $-\mathrm{NH}_{2}$ functional groups. The existence of the $-\mathrm{OH}$ and $-\mathrm{NH}_{2}$ primary functional groups indicates the existence of active groups that play an active role in the adsorption process. The greater of concentration of $\mathrm{ZnCl}_{2}$ activator, indicate that the higher intensity of the spectra at the wave number around $3400 \mathrm{~cm}^{-1}$ and $1600 \mathrm{~cm}^{-1}$. Therefore, It shows that more and more active groups are open. The greater the active open group is expected to be able to increase the ability of Biochar adsorption of NPK macronutrients. After activation, coconut shell biochar is used for 

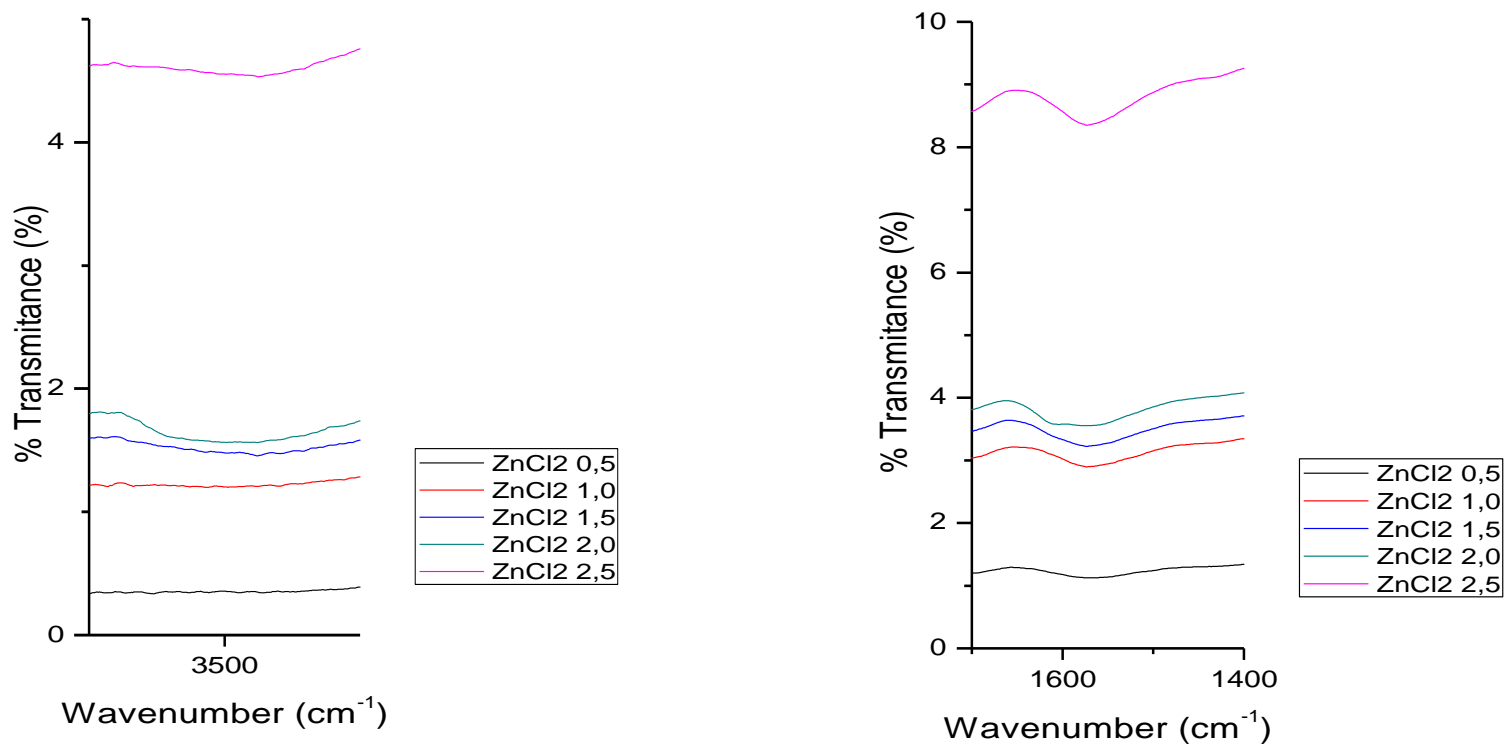

Figure 1. FTIR Spectra of Coconut shell Biochar with $\mathrm{ZnCl}_{2}$ activator variations.

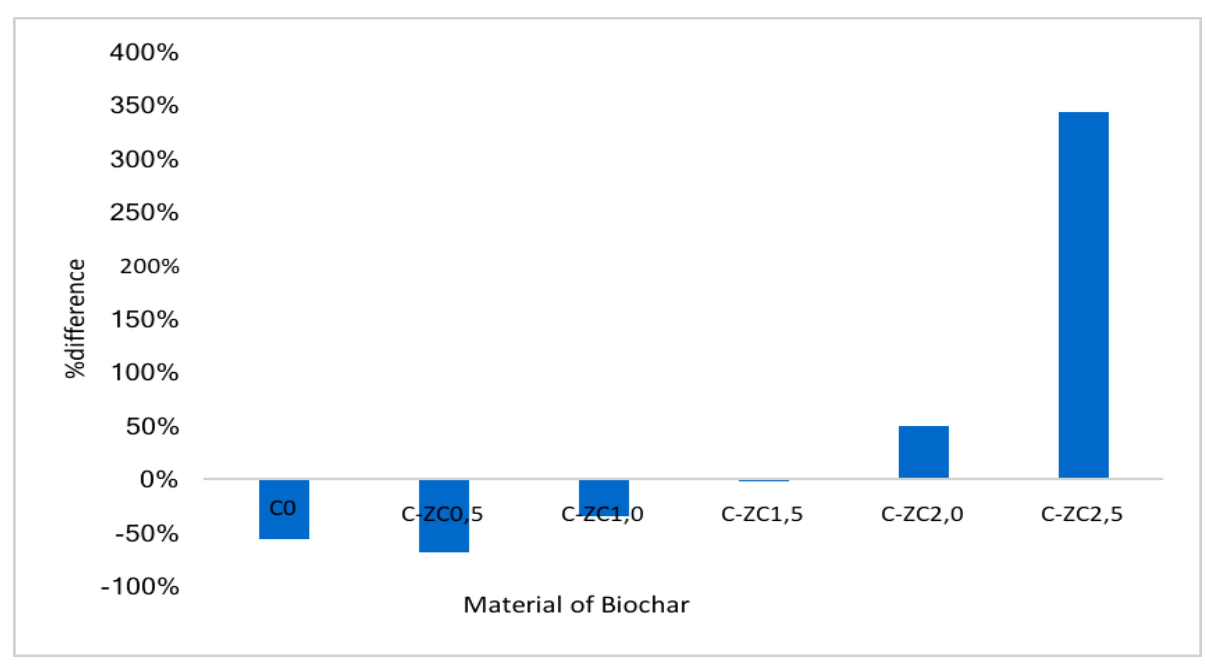

Figure 2. The concentration of Nitrogen $(\mathrm{N})$ before and after adsorption $(\mathrm{CO}=$ Carbon without activation; C-ZC0.5 = activation $\mathrm{ZnCl} 0.5 \mathrm{M} ; \mathrm{C}-\mathrm{ZCl} 1.0=$ activation $\mathrm{ZnCl} 1.0 \mathrm{M}, \mathrm{C}-\mathrm{ZC} 1.5=$ activation $\mathrm{ZnCl} 1.5 \mathrm{M} ; \mathrm{C}-\mathrm{ZC2} .0$ = activation $\mathrm{ZnCl} 2.0 \mathrm{M} ; \mathrm{C}-\mathrm{ZC} 2.5$ = activation $\mathrm{ZnCl} 2.5 \mathrm{M}$ )

Simultaneous (simultaneous) NPK macronutrient adsorption test. The change in NPK concentration between before and after adsorption as seen in Figure 2 until Figure 4.

Based on Figure 2, Biochar's adsorption capacity increases with an increased concentration of $\mathrm{ZnCl}_{2}$ activator. However, the concentration of Nitrogen in Biochar without activation, Biochar with a $0.5 \mathrm{M}$ to $1.5 \mathrm{M} \mathrm{ZnCl}_{2}$ activator obtained a negative change. These mean indicate that the concentration of Nitrogen after adsorption is smaller than before adsorption. This phenomenon is caused by the dissolution of Nitrogen in Biochar. This is due to the adsorption, desorption process, and the relatively weak bond between nitrogen and the active group of the adsorbent. With low activation of $\mathrm{ZnCl} 2$ activator, less open functional groups so that the nitrogen binding process by the adsorbent is weak. This causes the adsorption process to be weaker than the nitrogen desorption process in the adsorbent. wherein, the nitrogen in the adsorbent is the total nitrogen that comes from the adsorbent and the adsorbate solution. While the concentration of Nitrogen in Biochar with activator $\mathrm{ZnCl}_{2} 2.0 \mathrm{M}$ and $2.5 \mathrm{M}$ experienced positive changes. These mean indicate that the concentration of Nitrogen after adsorption is greater than before adsorption. The best condition is Biochar with $2.5 \mathrm{M} \mathrm{ZnCl}_{2}$ activator which is able to adsorb Nitrogen up to $343.02 \%$. 


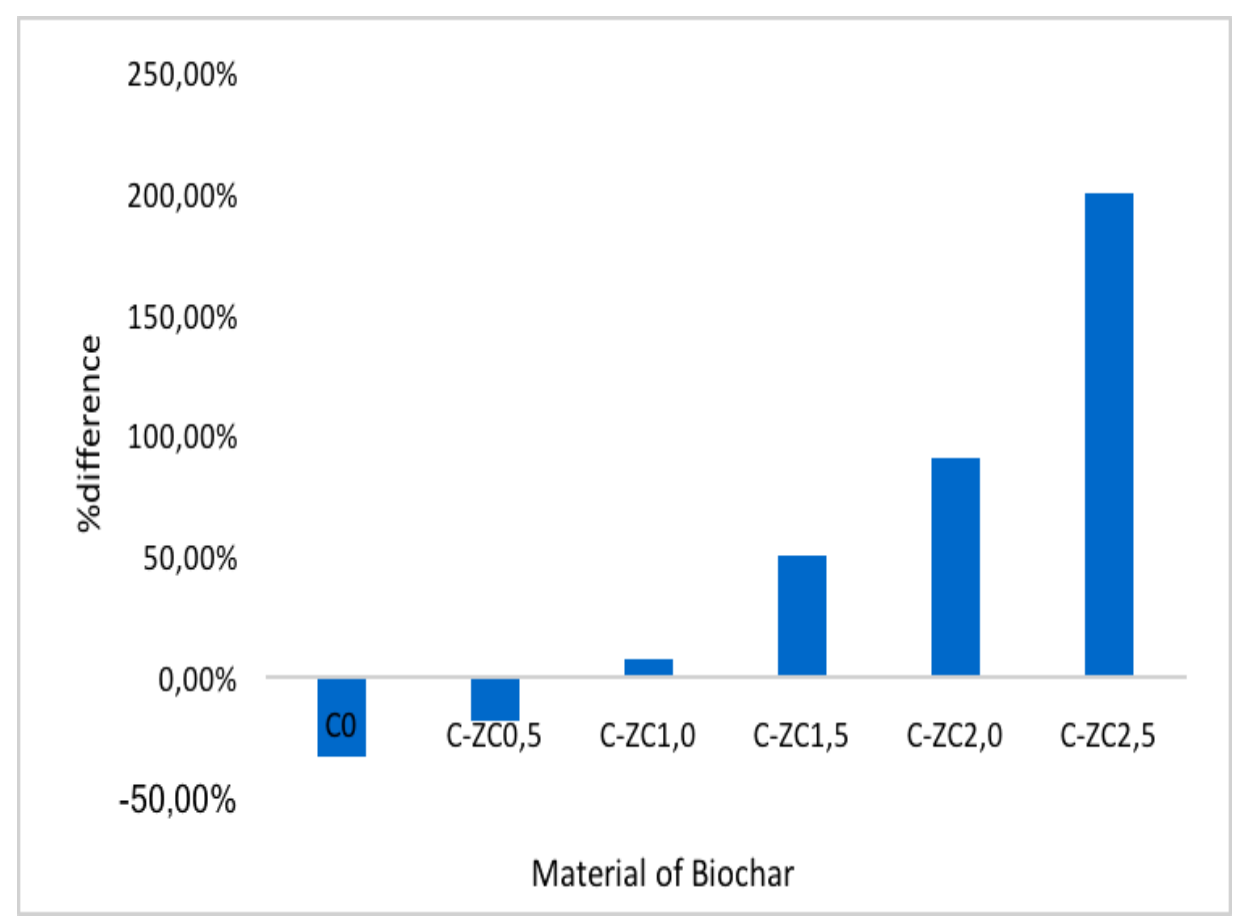

Figure 3. The Concentration of Phosphor (P) before and after adsorption $(\mathrm{C} 0=$ Carbon without activation; C-ZC0.5 = activation $\mathrm{ZnCl} 0.5 \mathrm{M} ; \mathrm{C}-\mathrm{ZCl} 1.0$ = activation $\mathrm{ZnCl} 1.0 \mathrm{M}, \mathrm{C}-\mathrm{ZC} 1.5$ = activation $\mathrm{ZnCl} 1.5 \mathrm{M} ; \mathrm{C}-\mathrm{ZC} 2.0$ = activation $\mathrm{ZnCl} 2.0 \mathrm{M} ; \mathrm{C}-\mathrm{ZC} 2.5$ = activation $\mathrm{ZnCl} 2.5 \mathrm{M}$ )

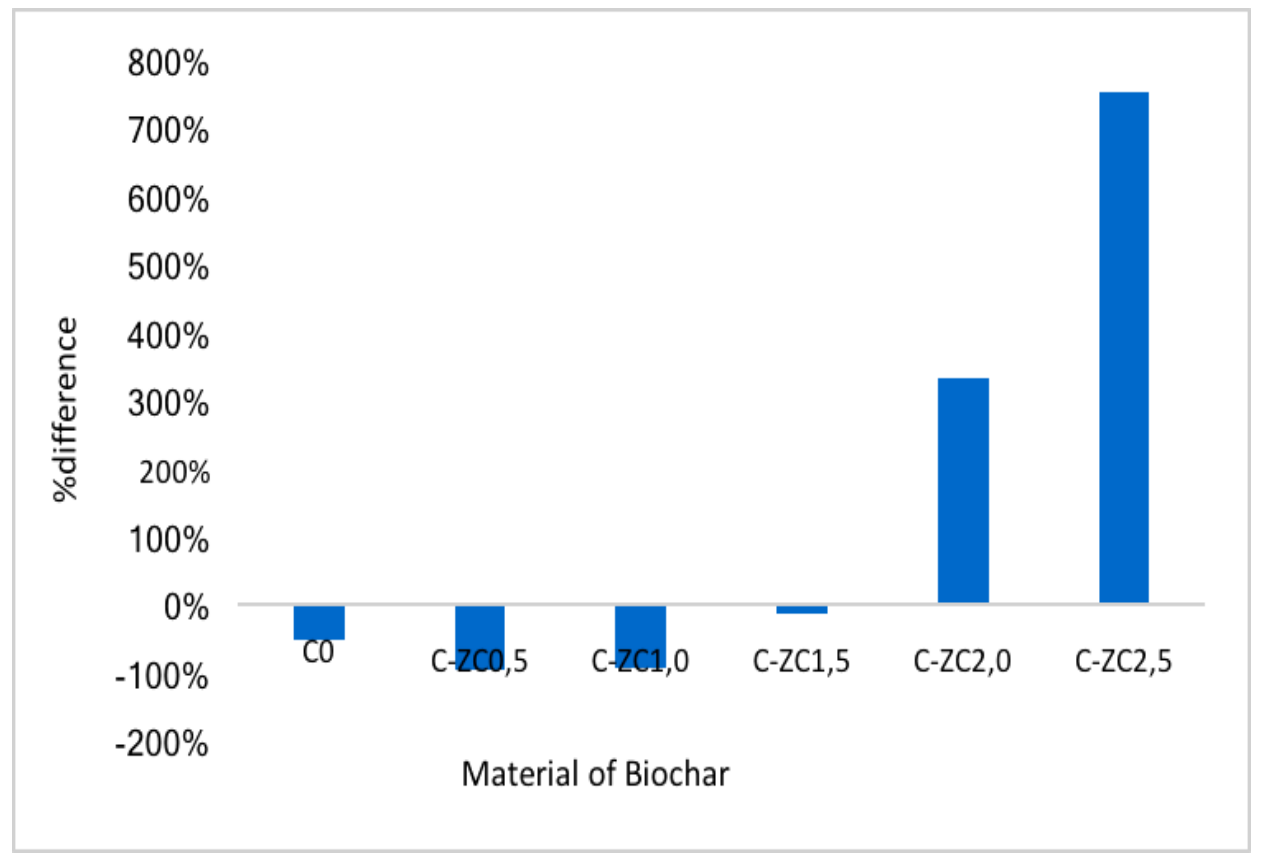

Figure 4. The Concentration of Potassium $(\mathrm{K})$ before and after adsorption $(\mathrm{C} 0=$ Carbon without activation; C-ZC0.5 = activation $\mathrm{ZnCl} 0.5 \mathrm{M} ; \mathrm{C}-\mathrm{ZC} 1.0$ = activation $\mathrm{ZnCl} 1.0 \mathrm{M}, \mathrm{C}-\mathrm{ZC} 1.5$ = activation $\mathrm{ZnCl} 1.5 \mathrm{M} ; \mathrm{C}-\mathrm{ZC} 2.0$ = activation $\mathrm{ZnCl} 2.0 \mathrm{M} ; \mathrm{C}-\mathrm{ZC} 2.5$ = activation $\mathrm{ZnCl} 2.5 \mathrm{M}$ )

Based on Figure 3, Biochar's adsorption capacity increases with an increased concentration of $\mathrm{ZnCl}_{2}$ activator. However, the concentration of Phosphor in Biochar without activation, and Biochar with $0.5 \mathrm{M}$ $\mathrm{ZnCl}_{2}$ activator experienced obtained negative changes. These mean indicate that the concentration of Phosphor after adsorption is smaller than before adsorption. This phenomenon is caused by the dissolution of Phosphor present in Biochar. While the concentration of Phosphor in Biochar with $\mathrm{ZnCl}_{2}$ activator $1.0 \mathrm{M}$ to $2.5 \mathrm{M}$ obtained positive changes. These mean indicate that the concentration of 
Phosphor after adsorption is greater than before adsorption. The effective condition is Biochar with 2.5 $\mathrm{M} \mathrm{ZnCl} 2$ activator which is able to adsorb Nitrogen up to $200 \%$.

Based on Figure 4, Biochar's adsorption capacity increases with an increased concentration of $\mathrm{ZnCl}_{2}$ activator. However, the concentration of Potassium in Biochar without activation, Biochar with a $0.5 \mathrm{M}$ to $1.5 \mathrm{M} \mathrm{ZnCl}_{2}$ activator obtained negative changes. These mean indicate that the concentration of Potassium after adsorption is smaller than before adsorption. This phenomenon is caused by the dissolution of Potassium in Biochar. While the concentration of Potassium in Biochar with $\mathrm{ZnCl}_{2}$ activator $2.0 \mathrm{M}$ and $2.5 \mathrm{M}$ obtained positive changes. These mean indicate that the concentration of Potassium after adsorption is greater than before adsorption. The optimum condition is Biochar with $2.5 \mathrm{M} \mathrm{ZnCl}_{2}$ activator which is able to adsorb Potassium up to $753.33 \%$.

Based on previous results, the optimum biochar is then used as a soil additive to improve the ability of the soil to absorb NPK macronutrients with a composition of $10 \%$ Biochar and $90 \%$ soil. The results of soil and Biochar-soil adsorption on NPK macronutrients as shown in Figure 5.

Figure 5 showed that the addition of Biochar with optimum activation can increase soil adsorption on NPK macronutrients. The addition of Biochar can increase Nitrogen adsorption by up to $23.53 \%$, Phosphor up to $200 \%$, and Potassium up to $41.24 \%$ (Figure 5d). The ability of Biochar adsorption with $\mathrm{ZnCl}_{2} 2.5 \mathrm{M}$ activation is supported by surface area and pore volume as shown in Figure 6.

Figure 6 shows the total pore volume of Biochar with $2.5 \mathrm{M} \mathrm{ZnCl}_{2}$ activation $(0.1896 \mathrm{cc} / \mathrm{g})$ is greater than Biochar without activation $(0.1573 \mathrm{cc} / \mathrm{g})$ (Figure 6a). Greater total pore volume causes contact area or surface area is greater. The surface area of Biochar with $2.5 \mathrm{M} \mathrm{ZnCl}_{2}$ activation $\left(289.4 \mathrm{~m}^{2} / \mathrm{g}\right)$ is greater than Biochar without activation $\left(207.7 \mathrm{~m}^{2} / \mathrm{g}\right)$ (Figure 6b). This causes the ability of Biochar CZC2.5 adsorption $\left(\mathrm{ZnCl}_{2}\right.$ activation $\left.2.5 \mathrm{M}\right)$ is greater than the adsorption ability of Biochar without activation. The pore volume and surface area of Biochar will also affect the desorption process as shown in Figure 7.

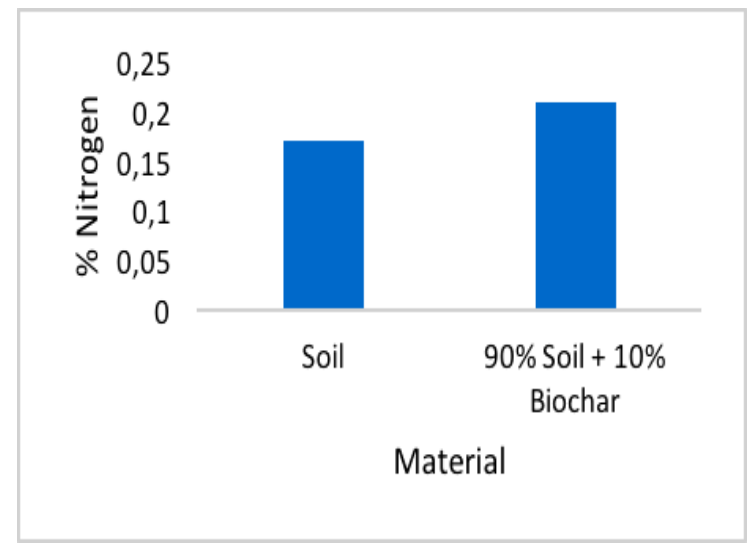

(a)

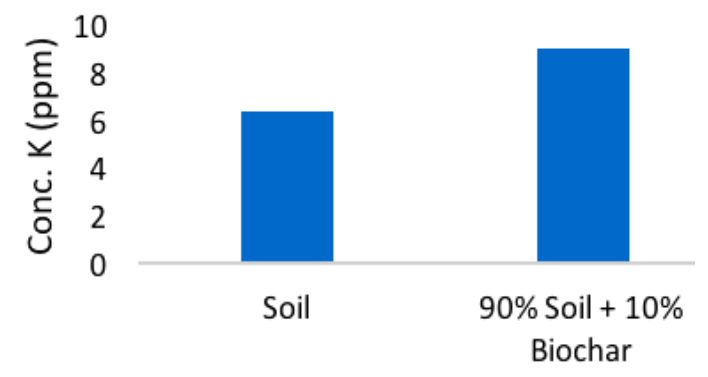

Material

(c)

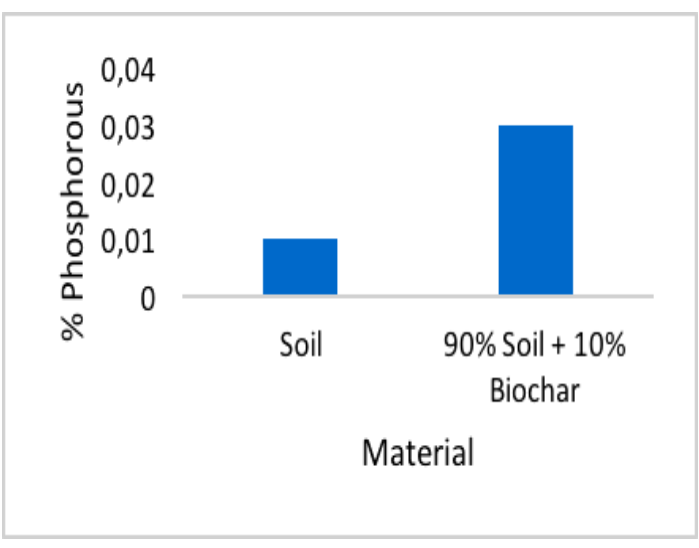

(b)

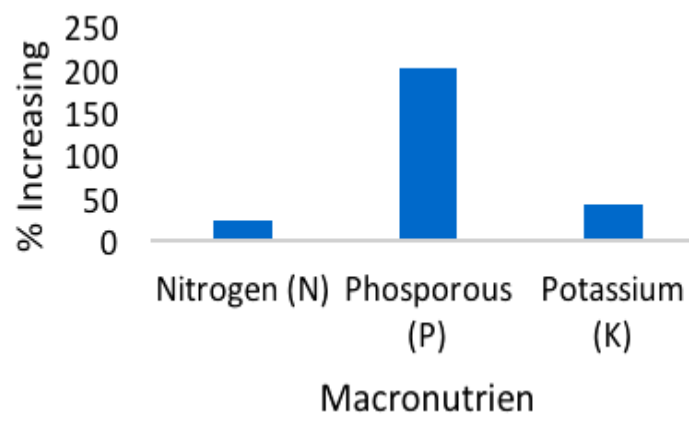

(d)

Figure 5. Adsorption of soils and Biochar-Soil to NPK macronutrients (a) Percentage (\%) of $N$, (b) Percentage (\%) of $\mathrm{P}$, (c) Percentage (\%) of K, (d) Percentage (\%) increasing macronutrient NPK in soil after addition Biochar 


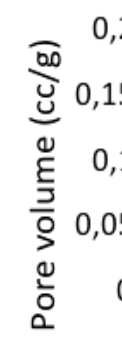

0,2

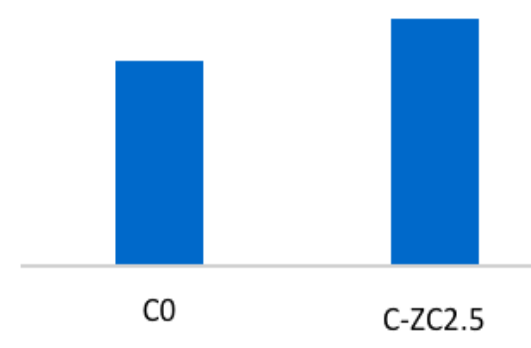

Material of Biochar

(a)

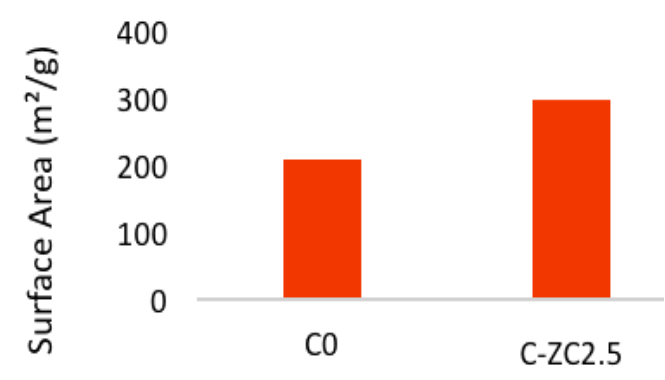

material of Biochar

(b)

Figure 6. (a). Pore volume $(\mathrm{cc} / \mathrm{g})$ dan (b). Surface area $\left(\mathrm{m}^{2} / \mathrm{g}\right)$ of Biochar

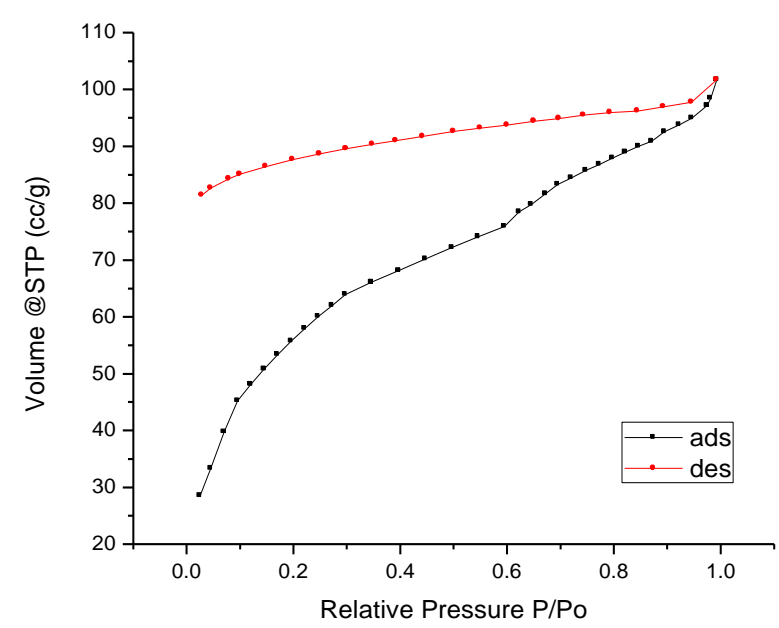

(a)

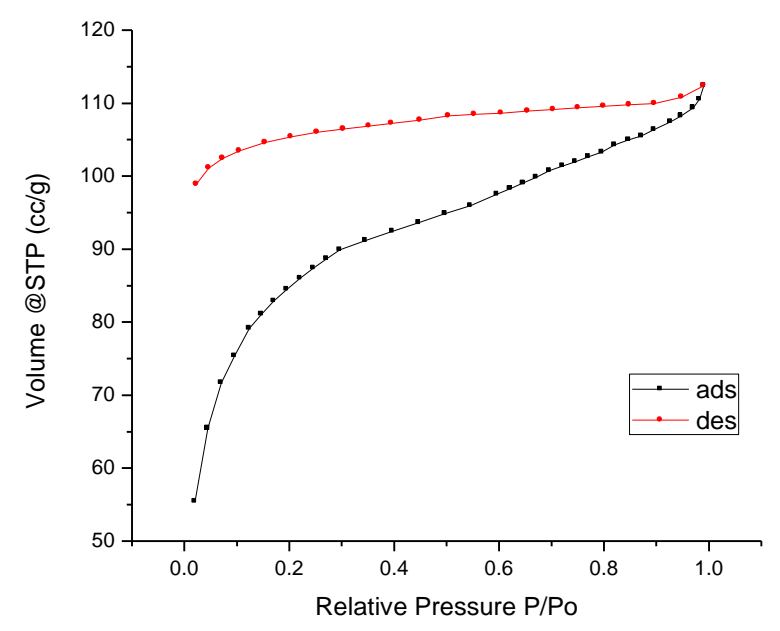

(b)

Figure 7. Adsorption and Desorption (a). Biochar without activation (CO), (b). Biochar with activation of $\mathrm{ZnCl} 22.5 \mathrm{M}$ (C-ZC2.5).

Figure 7 shows that the desorption process in Biochar with activation of $\mathrm{ZnCl} 22.5 \mathrm{M}$ (Figure $7 \mathrm{~b}$ ) is more difficult than Biochar without activation (Figyre 7a). This is because the volume of Biochar with activation of $\mathrm{ZnCl} 22.5 \mathrm{M}$ (C-ZC2.5) is greater than Biochar without activation (C0) so the adsorbate that is absorbed becomes higher and more difficult to be released. Absorption at the active site in the pore has the potential for a smaller desorption process than at the surface active site, especially in the physical adsorption process. This is indicated by the volume of $\mathrm{N} 2$ left behind in the Biochar desorption process with $2.5 \mathrm{M} \mathrm{ZnCl} 2$ activation (C-ZC2.5) greater than Biochar without activation (CO). This indicates the ability of Biochar with activation of $\mathrm{ZnCl} 22.5 \mathrm{M}$ (CZC2.5) in maintaining NPK macronutrients is greater than Biochar without activation (CO) so that NPK macronutrients are not easily separated.

\section{CONCLUSIONS}

Based on the research, it was concluded that the greater the concentration of $\mathrm{ZnCl}_{2}$ activator, indicated that the higher intensity of the spectra of $\mathrm{OH}$ and $-\mathrm{NH}_{2}$ at wave number $3400 \mathrm{~cm}^{-1}$ and 1600 $\mathrm{cm}^{-1}$. It showed that biochar activation was higher and a more active functional group was opened.. Increasing the concentration of $\mathrm{ZnCl}_{2}$ activator has increased Biochar adsorption of NPK macronutrients. The optimum condition for activation of coconut shell Biochar is activation with $\mathrm{ZnCl}_{2} 2.5 \mathrm{M}$. The addition of optimum Biochar has increased soil adsorption on NPK macronutrients. The addition of Biochar can increase Nitrogen adsorption up to $23.53 \%$, Phosphor up to $200 \%$, and Potassium up to $41.24 \%$.

\section{ACKNOWLEDGMENT}

This study was supported by the Minister of Research, Technology and High Education, Republic of Indonesia in research grand project PPKI 2019.

\section{REFERENCES}

Belarovi, K., Seghier, A., \& Hadiel, M. (2014). Synthesis of activated carbon based on apricot stones for wastewater treatment. Desalination and water treatment 52, 1422-1433

Cazetta, A.L., Vargas, A.M.M., Nogami, E.M., Kunita M.H., Guilherme, M.R., Martins, A.C., Silva, T.L., Moraes, J.C,G., \& Almeida, V.C. (2011). $\mathrm{NaOH}$-activated carbon of high surface area produced from coconut shell: Kinetics and 
equilibrium studies from the methylene blue adsorption. Chemical Engineering Journal 174(1), 117-125.

Demiral, H., \& Uzun, I. (2010). Preparation and characterization of activated carbons from poplar wood (Populus L.). Surface and Interface Analysis 42, 1338-1341.

El-Dars, F.M.S.E., Ibrahim, M.A., \& Gabr, A.M.E. (2014). Reduction of COD in water-based paint wastewater using three types of activated carbon. Desalination and Water Treatment 52, 2975-2986.

Esterlita, M.O., \& Herlina, N. (2015). Effect of activators $\mathrm{ZnCl}_{2}, \mathrm{KOH}$, and $\mathrm{H}_{3} \mathrm{PO}_{4}$ in making activated carbon from palm fronds (Arenga pinnata). Jurnal Teknik Kimia USU 4(1), 47 52.

Gurten, I.I., Ozmak, M., Yagmur, E., \& Aktas, Z. (2012). Preparation and characterisation of activated carbon from waste tea using $\mathrm{K}_{2} \mathrm{CO}_{3}$. Biomass and bioenergy 37, 73-81.

Hawkesford, M., Horst, W., Kichey, T., Lambers, H., Schioerring, J., Møller, I. S., \& White, P. (2012). Functions of Macronutrients: Marschner's Mineral Nutrition of Higher Plants. 3rd editon. UK. Pergamon

Idrus, R., Lapanporo, B.P., \& Putra, Y.S. (2013). The effect of the activation temperature on the quality of activated carbon made from coconut shells. Prisma Fisika 1(1), 50 - 55.

Masitoh, Y.F., \& Sianita, M.M. (2013). Utilization Of (Theobroma Cacao. L) Cacao Skin For Activated Carbon As Adsorbent Cadmium (II) In Solution. UNESA Journal of Chemistry 2(2), $23-28$.
Mistar, E.M., Ahmad, S., Muslim, A., Alfatah, T., \& Supardan, M.D. (2017). Preparation and characterization of a high surface area of activated carbon from Bambusa vulgarisEffect of $\mathrm{NaOH}$ activation and pyrolysis temperature. IOP Conference Series: Materials Science and Engineering, 334, 1, 12051

Pambayun, G.S., Yulianto, R.Y.E., Rachimoellah, M.M., \& Putri, E.M.M. (2013). Preparation of activated carbon from coconut shell charcoal using $\mathrm{ZnCl}_{2}$ and $\mathrm{Na}_{2} \mathrm{CO}_{3}$ activators as adsorbents to reduce phenol levels in wastewater. Jurnal Teknik ITS 2(1), F116-F120.

Praing, M.W., Situmeang, Y.P., \& Mahardika, I.B.K. (2018). The Use of Different Types of Biochar and Fertilizers in Increasing Growth and Yield of Sweet Corn. Gema Agro 23(2), 176 - 181.

Ramdja, A.F., Halim, M., \& Handi, J. (2008). Activated Carbon Production From Coconut Fronds (Cocus nucifera). Jurnal Teknik Kimia, $15(2), 1-8$.

Rosas, JM., Bedia, J., Mirosol, J.R., \& Cordero, T. (2010). On the preparation and characterization of chars and activated carbons from orange skin. Fuel Processing Technology 91(10), 1345-1354.

Tanasale, M.F.J.D.P., Killay, A., \& Laratmase, M. S. (2012). Chitosan from crab shell waste (Portunus sanginolentus L.) as adsorbent of methylene blue dye. Jurnal Natur Indonesia $14(2), 165-171$.

Wijayanti, A., Susatyo, E.B., Kurniawan, C., \& Sukario (2018). Adsorption of $\mathrm{Cr}(\mathrm{VI})$ and $\mathrm{Cu}$ (II) Metals on Soil and Effect of Addition of Organic Fertilizer. Indonesian Journal of Chemical Science 7(3), 242-48. 